\title{
COMPARATIVE ANALYSIS OF FOREIGN AND NATIONAL EXPERIENCE OF UKRAINE IN ADMINISTRATION OF VALUE ADDED TAX
}

\author{
Anatolii Kislyi ${ }^{1}$ \\ Educational and Scientific Institute of Law, Interregional Academy of Personnel Management, Ukraine \\ Bohdan Stetsiuk ${ }^{2}$ \\ Educational and Scientific Institute of Law and Psychology of National University "Lviv Polytechnic", Ukraine \\ Inna Kovalenko ${ }^{3}$ \\ Educational and Scientific Humanitarian Institute of V.I. Vernadskyi's Taurian National University, Ukraine
}

\begin{abstract}
The aim of the article is to carry out a comparative analysis of foreign and national experience in the administration of value added tax; to outline the content of this tax, to define its role in the tax systems of foreign countries, as well as clarify the features of charging value added tax in individual foreign countries. The subject of the study is foreign and national experience of Ukraine in the administration of value added tax. Methodology. The methodological basis of this research is a comparison of the features of the administration of value added tax in Ukraine and foreign countries. Based on the aspects of the administration of VAT in Canada, Belgium, France, Great Britain, and others, the advantages and disadvantages of different conditions for charging VAT are highlighted. On the basis of the comparative legal analysis, the possibilities of the application and implementation of foreign experience in the national VAT administration are determined. The results of the study revealed that, in the activities of tax authorities, international experience of the administration of value added tax implies the consolidation of rigorous methods of influencing tax entities through applying appropriate penalties. However, this aspect is combined with a high level of legal awareness and law-abidingness of tax entities. In addition, foreign experience involves the active use of information technology in the administration of VAT, which facilitates its charging and increases its efficiency. Practical implications. Positive international experience of the administration of VAT confirms that improvement of the quality of this mechanism requires providing centralization of the tax administration in the state; intensifying the implementation of the latest technologies in this process; increasing citizens' legal consciousness in taxation, and so force. Relevance/originality. A comparative analysis of the features of the administration of value added tax is the basis for the development of national experience in this field.
\end{abstract}

Key words: value added tax, tax administration, foreign experience.

JEL Classification: E62, H71, F38

\section{Introduction}

Without doubt, independence of Ukraine is a positive factor for the development of democratic tendencies of our country. However, independence in all internal and external relations has necessitated the development of political and economic sectors of the country. In this context, the issue of improving the tax system was particularly acute, since the old model was not acceptable due to, first, the change of the economic vector from the planned-command to market direction, and, second, the active introduction of international standards in taxation. At the same time, the main task of the tax system evolution is to ensure its stability, which, in turn, should lead to a number of positive factors:

\footnotetext{
Corresponding author:

${ }^{1}$ Department of Security Management, Law Enforcement and Anti-Corruption Activities, Educational and Scientific Institute of Law, Interregional Academy of Personnel Management.

E-mail:kam_2000@ukr.net

${ }^{2}$ Department of History of State and Law, Educational and Scientific Institute of Law and Psychology of National University

"Lviv Polytechnic".

E-mail: sbr@gmail.com

${ }^{3}$ Department of Civil Law Disciplines, Educational and Scientific Humanitarian Institute of V.I. Vernadskyi's Taurian National University.

E-mail: ilchenkoi@ukr.net
} 
increase of financial revenues to the budget; improving the tax collection mechanism, etc.

It should be noted that the development of the tax system is a complex aspect, which involves solving a number of problems. In particular, in recent years, the relevance of the administration of value added tax (hereinafter referred to as VAT) has increased, since the latter is important for budget forming. Therefore, the theoretical development of this problem requires an analysis of foreign experience in the administration of VAT, for example, according to R.S. Melnyk, foreign experience contributes to expanding perceptions of legal phenomena under the study; helps to look at this or that issue from another perspective; compare own achievements with the achievements of foreign colleagues; do not waste time solving the problems that have already found solutions on the pages of foreign publications (Melnyk, 2010).

\section{Literature review}

The issue of the administration of value added tax has always been under thorough consideration of many foreign and domestic scientists. In particular, this issue was the subject of research of V.L. Andrushchenko, Yu.V. Bondar, O.V. Budko, Yu.A. Veryha, O.S. Husakov, M.Ya. Demianenko, Ya.V. Lytvynenko, V.M. Melnyk, S. Blancart, E. Dollan, J. Stiglitz and others. Meanwhile, the comparison of foreign and national experience in the administration of value added tax has not been studied exhaustively that underlines the relevance of this study.

The aim of the article is to conduct a comparative analysis of foreign and national experience in VAT administration and consider possibilities for its implementation in Ukraine.

\section{Main material}

It is worthy to note that the value added tax (hereinafter referred to as VAT) is a rather complicated and interesting economic and legal category. The VAT system was first proposed in Germany in 1919. Wilhelm von Siemens, who called it "Veredelte Umsatzsteuer" (translated as 'ennobled turnover tax'). At that time, this tax was called 'ennobled on turnover' or 'ennobled turnover tax'. Later, namely in 1921, Thomas S. Adams proposed to introduce VAT in the form of a business tax, as a substitute for the US corporate income tax. Initially, these proposals were ineffective, and the introduction of this tax was of no need. However, from time to time, tax authorities from different countries referred to the ideas of Wilhelm von Siemens and Thomas S. Adams. The need to eliminate the shortcomings of the turnover tax and the growth of fiscal needs prompted the search for alternative types of indirect taxation. The modern scheme of this tax was developed and described by French economist M. Lauré in 1954 (Azarov, et al., 2004; Korolchuk, 2010).

These days VAT is widely used in many countries, including Ukraine. Of course, since the middle of the twentieth century, the essence of this tax has changed. In this study, it is advisable to outline the concept of VAT. Thus, according to Article 14 of the current Tax Code of Ukraine (hereinafter - the TCU), the value added tax is an indirect tax that is calculated and paid in accordance with the rules of the current legislation (Podatkovyi kodeks Ukrainy, 2010). Obviously, the legislative interpretation of VAT does not reveal the content and purpose of the tax, therefore, quite often, researchers introduce their own definitions of this category.

In particular, according to economic science, the value added tax is a type of tax that is charged not on the total value of the goods, but on its increase at each subsequent stage in the overall chain of sales and production. Ultimately, the difference between the proceeds from the sale of goods and services and the amount of raw material, semi-finished products and services received from suppliers is subject to the tax (Ambartsumov, Sterlykov, 1993; Vaschenko, 2003).

According to G.V. Bekh and S.G. Pepeliaieva, VAT is a multi-stage, indirect tax, which serves a part of the newly created value, included in the price of the sale of goods (works, services) and paid by the consumer of these goods (works, services) to the State budget at each stage of production of goods, performance of works, provision of services. Its charging at each stage of the turnover gives VAT universality and inevitability (Kucheriavenko, 2001; Bekh, 2001).

T.M. Semenenko emphasizes that the value added tax is an indirect tax, which is part of the newly created value of goods (works, services) that is formed at each stage of production, turnover and is included in the price of the goods and paid by the end user. VAT is a tax on domestic consumption of products, in fact, an increase in the price of goods (works, services), which are consumed in the customs territory of Ukraine (Semenko, 2011).

Correspondingly, O.I. Okseniuk defines VAT as a consumption tax that is charged on the value added, created at each stage of production, paid by the end user and funded to the budget by the seller, except in cases of transactions with the participation of non-residents (Okseniuk, 2015; Podolianchuk, 2017).

In the same way, A.G. Ziunkin and L.K. Voronova define the value added tax as an indirect tax on goods and services, the main modern form of universal excise tax, which is established for the newly created value by the payer (Ziunkin, 2003; Voronova, 2006).

Consequently, the value added tax is an indirect, commission-determined tax that is calculated at each stage of production and is dependent on the type of enterprise, the tax system used on it, which payment entity is the final consumer. 
This tax is known in many foreign countries, and, consequently, the mechanisms of its administration vary. Nevertheless, before determining the foreign experience of the VAT administration, it is necessary to answer the question of what the administration of taxes is in general.

The etymological basis of the concept is the term "to administer," which according to the provisions of interpretative dictionaries means:

1) to manage an institution, organization, enterprise;

2) to supervise in bureaucratic manner, using orders and commands instead of a specific guiding (Busel, 2005; Bilodid, 1970).

Meanwhile, in the context of tax administration, this concept is interpreted more broadly than purely management or supervision, according to a large number of scientists. A.O. Selivanov claims that tax administration is legal relations that are drawn up in the implementation of measures for repayment of tax debt by the authorized state bodies and provide for the application of methods of compelling and compulsory nature to taxpayers (Selivanov, 2002; Lastovetskyi, 2004).

V.B. Marchenko considers the administration of taxes as an administrative process in the field of tax charging, that is, as a procedure established by law for the consideration and resolution of individual (administrative) cases that arise in the field of tax charging by specifically authorized bodies (tax administrators) and, in certain cases, by competent courts (Marchenko, 2009).

Professor A.Z. Dadashev considers tax administration exclusively from the perspective of tax control (Dadashev, 2002). In turn, I.P. Vakulich considers the form of tax revenues, specificities of taxation in various sectors of the economy and spheres of activity, the write-off and restructuring of tax debt, reduction of the tax base, application of the system of benefits, and so on to be tax administration (Vakulych, 2003).

Some researchers argue that tax administration is manifested through established by law rights and obligations of taxpayers, authorities of the State Tax Service and other supervisory bodies (Nikitina, 2002; Pryshva, 2004).

However, evidently, the most complete and correct definition of the concept of tax administration is stated in the provisions of the Tax Code of Ukraine. In accordance with Article 14 of the TCU, the administration of taxes, duties, customs duties, a single compulsory state social insurance contribution and other payments in accordance with the legislation, which is monitored by the controlling bodies is a set of decisions and procedures of the controlling bodies and actions of their officials, which determine the institutional structure of tax and customs relations, organize the identification, registration of taxpayers and payers of the single contribution and objects of taxation, provide service for taxpayers, organize and control the payment of taxes, fees, payments in accordance with the procedure established by law (Podatkovyi kodeks Ukrainy, 2010).

Therefore, based on the legally established definition, the tax administration is an integral legal mechanism, that is, a set of relevant procedures, decisions and regulations through which the taxation is managed in Ukraine. Consequently, the administration of VAT is the branch of the classical administration mechanism. However, S.M. Gritsa states that so far the administration of the value added tax has not been considered enough in the scientific literature. Some authors consider accounting of taxpayers, defining the object of taxation and VAT rates, tax exemptions, the procedure for calculating and paying the VAT, accounting for calculations of the VAT with the budget, and so on to be the main functions and procedures for administration of the VAT (Value added tax, 2004; Hretsa, 2014). Therefore, in this research, consolidating the above-mentioned information, the concept of the value added tax administration is synthesized, according to which it is a mechanism of the state regulation of a VAT levy, as well as all related legal relations.

Considering foreign experience, nowadays the VAT is very actively used and developed in many European countries. In particular, E.S. Khoroshaiev argues that the value added tax is the perfect form of universal excise duties, which has become an integral part of modern European taxation. Its presence in the national fiscal system is one of the conditions for membership in the European Union (Khoroshaiev, 2008). Confirmation of this conclusion can be seen on the example of many countries.

For example, the value added tax is a key element of the French budget system. Objects of taxation are the price of goods and services. The main positive feature of the VAT is neutrality in relation to enterprises, as well as the reality and stability of budget revenues. This creates favorable conditions for the export of products. To a certain extent, the consumption of luxury items is discouraged. In France, the VAT comes fully to the central budget (Kharchenko, 2017).

It should be noted that the efficiency of this tax administration is explained by several aspects. First, in France, the VAT is charged at several rates. The key rate is of $18.6 \%$, and increased of $22 \%$. At the same time, the law provides for the existence of a reduced rate of $5.5 \%$, which is applied to most household goods and agricultural products, books and medicines. The same reduced rate is applied to certain types of services: tourist and hotel services, freight and passenger transportation, entertainment events, lunches for employees of enterprises (Kniazev, Chernik, 1997).

In addition, France has a Euro-continental model of taxation that is characterized by a high share of social security contributions, as well as a significant share of 
indirect taxes, consequently, indirect taxes account for about $60 \%$ of the tax revenues of the general budget of France. In this context, the VAT is applied to all operations of production and trade, and as a result, all business transactions carried out by both commercial organizations and private individuals are subject to tax (Ovcharenko, Rieznik, n.d.).

The key authority in the system of the value added tax administration and other mandatory payments provided for by French legislation is the Ministry of Economy, Finance and Industry. In the structure of this executive body there is a special department, the General Directorate of Taxes, whose authorities include a wide range of powers, in particular: implementation of tax control, examination of taxation issues, and so forth (Tax Liability in France, n.d.).

It should also be noted that France is one of the countries with a special regime for the payment of the value added tax in agriculture, which, in turn, is implemented in two standard forms. The latter differ from each other by the payment regime, accounting and tax composition of entities. For example, there is a regime of the tax on total turnover (the farmer keeps a journal of chronological accounting of sales and the VAT, and also stores the invoices received during purchases for the final calculation of the year) and the regime with the option for entrepreneurs engaged in intra-industry trade (for example, trade in cattle) (Bezkrovnyi, 2012).

The experience of the VAT administration in Belgium is interesting to analyze. In this state, the value added tax is levied on a consumer in a consistent manner during the conclusion of each transaction in the production and distribution process, in particular in the supply of goods and services in of Belgium and the purchase of goods outside the EU. Each VAT payer includes the VAT in the price of the product when selling. Finally, the tax is paid by the end user, who cannot deduct the VAT paid on purchase. At the legislative level, several types of tax rates have been introduced, which vary according to the type of entrepreneurial activity. In addition, taxpayers may submit VAT returns on a quarterly basis, depending on whether the threshold for deliveries exceeds 1,000,000 EUR (not including the VAT) annually (Kmit, Shuhailo, 2017). Taxpayers, whose business is in areas such as mobile phones, computers, and vehicles, may only use this option under certain conditions. Taxpayers, who file a tax return on a quarterly basis, must pay a tax in the first and second months of the quarter. Taxpayers, who submit a monthly declaration must pay taxes at the end of December for December. All payments must be made via bank transfer. Notably, taxpayers have the right to choose independently their tax reporting form. Therefore, for today they can file a tax or electronic declaration of the VAT via a special information system "INTERVAT" (Pokyntelytsia, 2009; Kmit, Shuhailo, 2017). In addition, there are other specificities of Belgian value added tax administration mechanism, which is stated in the legal literature. L.V. Andrushchenko, Z.S. Varnalii, I.A. Prokopenko, T.V. Tuchak note that the key characteristics of the VAT administration in this country are:

1) no mandatory pre-registration for submission of VAT tax returns and additional information on intraEuropean transactions;

2) in order to ensure the confidentiality of the declarations filed through the Internet, the relevant information is encrypted using electronic signatures. Therefore, VAT payers must obtain appropriate certificates from the certification body or receive an electronic ID card reader;

3) the essential advantage of Belgian system is that the necessary data for VAT authorities regarding VAT obligations can be either manually made in the required forms or downloaded as a separate file from the accounting software, etc. (Andrushchenko et al., 2012; Drahalchuk, 2017).

In the United Kingdom, where both direct and indirect taxation are equally developed, a leading role in the system of the latter plays the value added tax. Due to it, in the country, up to $17 \%$ of consolidated budget revenues are formed. There are three tax rates: $0 \%, 5 \%$ and $17.5 \%$, some of the objects are exempt from taxation. The controlling and monitoring system for VAT payers' activity is based on the mechanism of voluntary registration. All payers, who have completed at least one business transaction in excess of 5,500 pounds, are subject to registration. The tax authority assigns a taxpayer a registration number (Andrushchenko, 2004; Proskura, 2012).

The Treasury, which is constitutional and has the status of the main ministry, conducts the administration of VAT and other taxes in the UK. Practical administration is carried out by two structural subdivisions of the Treasury: the Internal Revenue Service and HM Customs and Excise. It should be noted that in the UK, tax authorities carefully monitor transactions of only $15 \%$ of taxpayers who provide up to $70 \%$ of tax revenues. Therefore, the cost of controlling and monitoring of their activities can be lowered and more attention can be paid to those who provide the highest income. At the same time, control over the activities of other payers is based on a risk-oriented system, which involves conducting regular routine inspections according to the standard procedure (Popova, 2011; Proskura, 2012).

In Germany, the VAT administration mechanism has specificities. In this country, there is a standard VAT rate $(16 \%)$ and a reduced rate $(7 \%)$, which deals with food products (except drinks), print publications, hotel services, public catering establishments and public transport. There is a well-developed system of local taxation. A key aspect of the German model of administration, not only VAT, but all other statutory mandatory payments and fees, is rather high and severe 
financial penalties for tax offenses, which, in turn, stimulates the vast majority of taxpayers to pay taxes voluntarily in due time. It is also important to note that there is no single tax administration in Germany, and tax collection and tax control functions are assigned to various structural subdivisions of the Federal Ministry of Finance and the Ministry of Lands (Karlin, 2004; Proskura, 2012).

Bulgarian foreign experience in the VAT administration is noteworthy. In particular, it is the first country to implement the idea of creating special VAT accounts. For such accounts, there is a special regime of use: cash is credited and written off only for VAT transactions or payments to other taxpayers (Yarosh, n.d.). Such an approach significantly reduces the corruption component in charging VAT, and increases the budget-forming aspect of this tax.

Therefore, based on the experience of many European countries where VAT is used as one of the key budget supplementing instruments, its administration, regardless of the type of tax system of a particular state, develops constantly towards increasing the efficiency of VAT collection, and is open for introduction of innovative technologies. However, the value added tax is known not only in European countries. It is actively used in many other countries, whose experience in administering this tax should also be considered.

For example, in Japan from April 1, 1989, along with the introduction of a new tax system a new for Japan tax, a tax on consumption, was introduced. This tax is levied on all transactions in the sale of goods and services, except cases specified in the legislation. The tax is paid at different stages of production and sales of goods, but only the added value is taxed. That is, in essence, it is a value added tax (Azarov, et al., 2004). It should be noted that in Japan, VAT is calculated using the balance sheet method, an alternative to the commonly used credit method. The balance sheet method is based on the calculation of the value added (wage costs, tax payments, depreciation, planned profit) and the application of a certain tax rate to it (Pasichnyk, 2015).

It should be emphasized that in Japan the mechanism of tax administration and VAT in particular differs greatly from its European analogue. This, above all, is due to the peculiarities of the tax system of this country. Thus, the Japanese tax system is oriented on the specific characteristics of the local population. The country has traditionally highly developed legal consciousness and law-abidingness, and the vast majority of citizens are simply not in a position to violate the law. The strength of this system is not in severity of punishment, but in the existing system of control over payers, which makes it practically impossible to evade the completion of the declaration. Of course, there are those who evade taxes. However, according to the law on the state control over tax violations, they can be subject to various sanctions, from fines to criminal prosecutions.
Japanese tax police works rigidly, consistently and fundamentally, regardless of individuals and positions (World tax experience, n.d.).

In addition to a rigid fiscal policy, the key to the effective administration of VAT in Japan is the high level of centralization of the tax collection. In particular, all state-defined mandatory payments and fees are divided into three groups: direct income taxes, direct taxes on property and direct and indirect consumer taxes, which are subject to VAT. In addition, all of them are sent to the state budget, and a single centralized system of tax authorities collect them (World tax experience, n.d.).

The value added tax also exists at the federal level in Canada, where it has a fiscal value. The peculiarities of its administration are connected, first of all, with the specifics of the tax system of the state. Thus, the latter is based on the principle of tax federalism, which implies the presence of significant powers of regional and local authorities in taxation (Tkachenko, 2004). The administration of VAT and all other taxes in Canada is carried out by the Canadian Customs and Revenue Agency, which reports to the Parliament through the Minister for National Income. This agency also administers most local taxes, but local authorities make a certain fee for the service. In some provinces, the administration of local taxes is carried out by regional authorities (the ministry of income of a certain region). Tax administration fees in Canada make up about 1\% of tax collections. Every year, tax authorities check on-site about $2 \%$ of taxpayers. All payers are divided into four categories by risk of committing an offense. Most often, payers with the highest levels of risk are checked (Proskura, 2012). According to K.P. Proskura, the high efficiency of the administration of VAT and all other taxes in Canada is due to a generally rational and flexible tax policy that organically takes into account the interests of all, the state and territories and taxpayers (Proskura, 2012).

A large number of specific features has the administration of VAT in Israel. Along with many European countries, in Israel, VAT plays a key role in indirect taxes. It was introduced in 1976. It should be noted that about 700 tax officials are involved in the collection of this tax. There are about 1,000 taxpayers (mostly commercial enterprises) per one tax official. To control the payment of VAT, all payers are categorized as large, medium and small according to the volume of activity. This differentiation enables to focus on those payers who pay large amounts, by the principle of "Pareto," $20 \%$ of the determined effort gives $80 \%$ of the results. This enables effective control over taxpayers at a minimal cost. One of the key features of the VAT administration is the requirement for obligatory registration of all taxpayers (Global tax experience, n.d.).

It should be noted that the presence of the value added tax in almost all countries of the post-Soviet area emphasizes the need to consider the mechanism of its administration in these states. One of the most 
progressive in this area is the experience of Belarus. According to T.V. Sydorova and E.V. Komliev, VAT is one of the two indirect taxes most often paid and one of the taxes most often charged in general. VAT is an indirect multi-stage tax, as it is included in the price of the product and ultimately paid by the end user (Komlev, Sidorova, 2017). The object is the added value, while the entities, in accordance with the Tax Code of the Republic of Belarus, are:

- organizations;

- individual entrepreneurs;

- the trustees for the turnover of the sale of goods (works, services), property rights arising in connection with trust management of property;

- individuals in cases determined by law (The Tax Code of the Republic of Belarus, 2009).

Analyzing the current mechanism of the administration of VAT in the Republic of Belarus, L.N. Lykova admits an inherent "aggressive model", in particular, in the tax control. The latter is characterized by a noticeable punitive character, which manifests itself in a range of sanctions for violation of tax laws (Lykova, 2015).

However, the Republic of Belarus is among the countries where information technology is being actively introduced into the VAT administration mechanism. Therefore, today according to Article 106-1 of the Tax Code, a special electronic invoice operates in the administration of VAT system. The latter is a mandatory electronic document for all VAT payers who have an object of value added tax or an obligation to submit an electronic invoice, and it is the basis for calculating value added tax between the seller and the buyer and deducting amounts of VAT. Electronic document flow of electronic invoices between sellers and buyers is carried out using the Portal of electronic invoices, which is an information resource of the Ministry of Taxes and Duties of the Republic of Belarus (The Tax Code of the Republic of Belarus, 2009).

\section{Conclusions}

Therefore, the value added tax acts as an effective fiscal instrument in many countries of the world, since it can provide significant revenues to the state budget. That is why, in most countries, the VAT administration mechanism improves constantly. In Ukraine, nowadays one of the key places in indirect taxation belongs to VAT. Consequently, it would be advisable to adopt and implement relevant experience in the VAT administration in Ukraine, in particular:

1) to optimize the size and scope of VAT rates according to the standards of European countries, for example, France, Great Britain, Belgium, etc.;

2) to intensify the implementation of innovative technologies in the activities of tax authorities to improve the quality and efficiency of implementation of the mechanism of the administration of VAT;

3) to centralize the mechanism of tax administration, as well as strengthen the powers of the controlling bodies of the branch and sanctions for violation of the legislation in the VAT collection by the pattern of the Republic of Belarus and Israel;

4) to increase the awareness of the country's population in taxation by the pattern of Japan, explaining the rights and obligations to prevent illegal behavior.

Therefore, the use of this experience will become a pledge of further development of the administration of value added tax, which, in turn, will determine its effectiveness in filling the budget of Ukraine.

\section{References:}

Ambartsumov A.A., Sterlykov F.F. (1993). 1000 termynov rynochnoi ekonomyky: Spravochnoe posobie [1000 Terms of the Market Economy: Reference Guide]. M. 299 p. (in Russian)

Andrushchenko, V.L. (2004). Podatkovi systemy zarubizhnykh krain [Tax systems of foreign countries]. K.:Computerpress, 240 p. (in Ukrainian)

Azarov, M.Ya., Yaroshenko, F.O., Melnyk, P.V. et al. (2004). Podatok na dodanu vartist: navchalnyi posibnyk [Valueadded tax: A teaching manual]. Irpin: NA STS of Ukraine, $396 \mathrm{p}$. (in Ukrainian)

Azarov, M.Ya., Yaroshenko, F.O., Melnyk, P.V. et al. (2004). Podatok na dodanu vartist: navchalnyi posibnyk [Value added tax: Textbook]. Irpin: NASTS of Ukraine, 396 p. (in Ukrainian)

Bekh, H.V. (2001). Pravove rehuliuvannia nepriamykh podatkiv v Ukraini [Legal regulation of indirect taxes in Ukraine] (Dissertation). Yaroslav the Wise's National Law Academy of Ukraine, Kharkiv, 207 p. (in Ukrainian)

Bezkrovnyi, O.V. (2012). Zarubizhnyi dosvid spravliannia podatku na dodanu vartist v silskomu hospodarstvi [Foreign experience of collecting value added tax in agriculture]. In O.V. Bezkrovnyi, K.S. Fuha. Naukovi pratsi Poltavskoi derzhavnoi ahrarnoi akademii, 4 (3). Ekonomichni nauky [Economics], 9-13. Poltava: PDAA. (in Ukrainian)

Bilodid, I.K. (1970). Slovnyk ukrainskoi movy [Ukrainian language dictionary]. (Vol. 1). Kyiv: Naukova dumka, 827p. (in Ukrainian)

Busel, V.T. (2005). Velykyi tlumachnyi slovnyk suchasnoi ukrainskoi movy [Great explanatory dictionary of modern Ukrainian language]. K., Irpin: PTF Perun, 1728 p. (in Ukrainian)

Dadashev, A.Z. (2002). Nalohovoe administrirovanie v Rossiiskoi Federatsii [Tax Administration in the Russian Federation]. M.: Knyzhnyi mir, 173 p. (in Russian) 
Drahalchuk, T.S. (2017). Yevropeiski tendentsii rozvytku administruvannia PDV [European Trends in the Administration of VAT]. Mezhdunarodnyi nauchnyi zhurnal 'Internauka' [International scientific magazine "Internascience"'], 1(23), 51-55. (in Ukrainian)

Hretsa, S.M. (2014). Teoretychni aspekty vyznachennia ponyattia administruvannia podatku na dodanu vartist [Theoretical aspects of definition of the concept of administration of value added tax]. Naukovyi visnyk Mizhnarodnoho humanitarnoho universytetu [Scientific Bulletin of the International Humanitarian University], 8, 74-76. (in Ukrainian)

Karlin, M.I. (2004). Finansy zarubizhnykh krain: navchalnyi posibnyk [Finances of foreign countries: Textbook]. K.: Kondor, 384. (in Ukrainian)

Kharchenko, N.V. (2017). Podatok na dodanu vartist yak element torhovykh vidnosyn mizh derzhavamy [Value added tax as an element of trade relations between states]. Materialy Mizhnarodnoi naukovo-praktychnoi konferentsii "Rozvytok sotsialno-ekonomichnykh system $v$ heoekonomichnomu prostori: teoriia, metodolohiia, orhanizatsiia obliku ta opodatkuvannia" [Materials of the International scientific and practical conference "Development of socio-economic systems in the geo-economic space: theory, methodology, organization of accounting and taxation"], 181-182. (in Ukrainian)

Khoroshaiev, Ye.S. (2008). Zakonodavche rehulyuvannia PDV ta shliakhy yoho udoskonalennia [Legislative regulation of VAT and ways of its improvement]. Chasopys Kyivskoho universytetu prava [Journal of the Kyiv University of Law], 4, 111-117.

Kmit, V.M., Shuhailo, D.O. (2017). Zarubizhnyi dosvid spravliannia PDV i dotsilnist yoho zastosuvannia v Ukraini [Foreign experience of VAT collection and expediency of its application in Ukraine]. Priazovskyi ekonomichnyi visnyk [Priazovsk Economic Bulletin], 5(05), 311-316. (in Ukrainian)

Kniazev, V.H., Chernik, D.H. (1997). Nalohovye systemy zarubezhnykh stran: uchebnyk dlia vuzov [Tax systems of foreign countries: a textbook for high schools]. M.: Zakon i parvo, UNITY. (in Russian)

Komlev, Ye.V., Sidorova, T.V. (2017). Problemy i sovershenstvovanie protsessa administrativnogo naloga na dobavlennuiu stoimost v Respublike Belarus [Problems and improvement of the process of administrative value added tax in the Republic of Belarus]. Elektronnyi nauchno-tekhnicheskiy zhurnal [Electronic scientific and technical journal]. Retrieved from: http://e.biblio.bru.by/bitstream/handle/1212121212/5139/Komlev.pdf?sequence=1. (in Russian)

Korolchuk, V.V. (2010). Zapobihannia zlochynam, poviazanym z vidshkoduvanniam podatku na dodanu vartist [Prevention of crimes related to the reimbursement of value added tax] (Dissertation). Kiev National University of Internal Affairs, Kiev, 330 p. (in Ukrainian)

Kucheriavenko, M.P. (2001). Osnovy podatkovoho prava: Navchalnyi posibnyk [Fundamentals of tax law: A teaching manual] (pp. 62-63). Kharkiv: Legas. (in Ukrainian)

Lastovetskyi, A.S. (2004). Orhanizatsiino-pravovi zasady rehuliuvannia pidpryiemnytskoi diialnosti $v$ Ukraini [Organizational and legal bases of regulation of entrepreneurial activity in Ukraine] (Dissertation). Kyiv Juridical Institute, Kyiv, 194 p. (in Ukrainian)

Lykova, L.N. (2015). Nalogi i nalogooblozheniie: uchebnik i praktikum dlia SPO [Taxes and taxation: A textbook]. M.: Publishing House Youwrite, 353 p. (in Russian)

Marchenko, V.B. (2009). Administratyvno-pravove rehulyuvannia u sferi spravlyannia podatkiv [Administrative and legal regulation in the field of tax collection] (Dissertation). National University of State Tax Service of Ukraine, Irpin, 212 p. (in Ukrainian)

Melnyk, R.S. (2010). Administratyvno-hospodarske pravo yak strukturnyi element systemy administratyvnoho prava: zarubizhnyi dosvid ta natsionalni osoblyvosti [Administrative and commercial law as a structural element of the system of administrative law: foreign experience and national features]. Pravo i bezpeka [Law and safety], 2(34), 55-59. (in Ukrainian)

Nalogovii kodeks Respubliki Belarus (osobennaia chast): zakon ot 29 dekabrya №71-3. [The Tax Code of the Republic of Belarus (special part): Law No. 71-3]. (2009). Retrieved from: http://nalog.gov.by/ru/article90/. (in Russian)

Nikitina, A.V. (2002). Pravovoe rehulyrovanie pohranichnoho vzaimodeistviia nalohovoho y biudzhetnoho zakonodatelstva [Legal regulation of frontier interaction of tax and budgetary legislation]. Finansy [Finances], 11, 32-36.(in Russian)

Okseniuk, O.I. (2015). Fiskalna efektyvnist podatku na dodanu vartist v ekonomitsi Ukrainy [Fiscal Efficiency of the Value Added Tax on the Economy of Ukraine]. (Dissertation). Lviv, 231 p. (in Ukrainian)

Ovcharenko, N.M., Rieznik, O.M. Porivnyalna kharakterystyka stavky podatku na dodanu vartist v Rumunii, Frantsii, Lyuksemburzi ta Ukraini Comparative characteristics of the value added tax rate in Romania, France, Luxembourg and Ukraine. Retrieved from: https://essuir.sumdu.edu.ua/bitstream/123456789/43878/3/ Reznik_Ovcharenko_Comparative_characteristics_rate_of_VAT.pdf. (in Ukrainian)

Pasichnyk, V.B. (2015). Systema uperedzhennia ryzykiv na rehionalnomu rivni z vykorystanniam danykh Yedynoho reyestru podatkovykh nakladnykh ta systemy avtomatyzovanoho spivstavlennia podatkovykh zoboviazan ta podatkovoho kredytu v rozrizi kontrahentiv [Regional risk prevention system using data from the Unified Register of Tax Bills and the Automated Comparison of Tax Obligations and Tax Credit by Contractors]. Kyiv: DFS of Ukraine Center for retraining and advanced training of senior managers of DFS bodies, 83 p. (in Ukrainian). 
Podatkovi systemy zarubizhnykh krain [Tax systems of foreign countries]. (2012). In L.V. Andrushchenko, Z.S. Varnalii, I.A. Prokopenko, T.V. Tuchak. Navchalnyi posibnyk NUDPS Ukrainy [The textbook NUSFS of Ukraine], 1,74-80, 116-127. (in Ukrainian)

Podatkovyi kodeks Ukrainy: zakon vid 02.12.2010 №2755-VI [The Tax Code of Ukraine: Law №2755-VI] (December 2, 2010). Vidomosti Verkhovnoi Rady Ukrainy [Bulletin of the Verkhovna Rada of Ukraine]. (2011). No. 13, No. 13-14, No.1 5-16, No. 17, p. 112. (in Russian)

Podatok na dodanu vartist: navchalnyi posibnyk [Value added tax: National tutorial]. (2004). Irpin: National Academy of Internal Affairs of Ukraine, 396 p. (in Ukrainian)

Podolianchuk, O.A. (2017). Podatok na dodanu vartist: sutnist ta stan pervynnoho obliku [Value added tax: Essence and condition of primary accounting]. Ekonomika. Finansy. Menedzhment: aktualni pytannia nauky $i$ praktyky [Business. Finances. Management: topical issues of science and practice], 1, 82-102. (in Ukrainian)

Pokyntelytsia, V. (2009).Zarubizhnyi dosvid administruvannia podatkiv [Foreign experience in tax administration]. Naukovyi visnyk [Scientific Bulletin of DHMA], 1(4E), 281-287. (in Ukrainian)

Popova, L.V. (2011). Nalohovye systemy zarubezhnykh stran [Tax systems of foreign countries]. M.: Delo i Servis. (in Russian)

Proskura, K.P. (2012). Zarubizhnyi dosvid orhanizatsii podatkovoho administruvannia [Foreign experience in the organization of tax administration]. Ekonomichnyi chasopys - XXI [Economic Journal- XXI], 7-8, 30-33. (in Ukrainian)

Proskura, K. (2012). Podatkove administruvannia u rozvynenykh yevropeyskykh krainakh [Tax administration in developed European countries]. Ekonomichnyi analiz [Economic analysis], 11(1), 203-206. (in Ukrainian)

Pryshva, N.Yu. (2004). Pravovi problemy rehuliuvannia oboviazkovykh platezhiv [Legal problems of regulation of obligatory payments] (Dissertation). Kiev National Taras Shevchenko University, Kyiv, 439 p. (in Ukrainian)

Svitovyi dosvid opodatkuvannia: Izrayil: stattia [Global tax experience: Israel: article]. Ofitsiinyi portal Derzhavnoi fiskalnoi sluzhby Ukrainy [Official portal of the State fiscal service of Ukraine]. Retrieved from: http://sfs.gov.ua/ arhiv/modernizatsiya-dps-ukraini/arkchiv/mijnarodniy-dosvid-rozvitk/svitovui-dosvid/israel/. (in Ukrainian)

Svitovyi dosvid opodatkuvannia: Yaponiia: stattia [World tax experience: Japan: article]. Ofitsinyi portal Derzhavnoi fiskalnoi sluzhby Ukrainy [Official portal of the State fiscal service of Ukraine]. Retrieved from: http:// sfs.gov.ua/arhiv/ modernizatsiya-dps-ukraini/arkchiv/mijnarodniy-dosvid-rozvitk/svitovui-dosvid/japan/. (in Ukrainian)

Selivanov, A. (2002). Administruvannia podatkiv: novi problemy v administratyvnomu ta finansovomu pravi Ukrainy [Administration of taxes: New problems in the administrative and financial law of Ukraine]. Pravo Ukrainy [The Law of Ukraine], 2, 34-38. (in Ukrainian)

Semenko, T.M. (2011). Podatok na dodanu vartist yak ekonomichna katehoriia [Value added tax as an economic category]. Efektyvna ekonomika [Effective economy], 4. Retrieved from: http://www.economy.nayka.com.ua. (in Ukrainian)

Tax Liability in France. Official portal of the Government of France. Retrieved from: https://www.impots.gouv.fr/ portail/international-particulier/tax-liability-france

Tkachenko, N. M. (2004). Podatkovi systemy krain svitu ta Ukrainy. Oblik i zvitnist: navch.-metod. posib. [Tax systems of countries of the world and Ukraine. Accounting and reporting: A teaching and methodological manual . K.: Alerta, $554 \mathrm{p}$. (in Ukrainian)

Vakulych, I.P. (2003). Podatkove administruvannia ta efektyvnist podatkovoi systemy [Tax administration and efficiency of the tax system]. Finansy Ukrainy [Finances of Ukraine], 2, 54-59. (in Ukrainian)

Vaschenko, Yu.V. (2003). Pravove rehuliuvannia klirynhovykh rozrakhunkiv [Legal regulation of clearing calculations] (Dissertation). Kyiv National Taras Shevchenko's University, Kyiv, 208 p. (in Ukrainian)

Voronova, L.K. (2006). Finansove pravo Ukrainy: pidruchnyk [Financial law of Ukraine: A teaching manual]. K.: Pretsedent; Moia knyha, 448 p. (in Ukrainian)

Yarosh, M.V. Podatok na dodanu vartist $\mathrm{v}$ umovakh yevrointehratsii osnovni ryzyky administruvannia [Value added tax in the conditions of european integration major administration risks]. Sotsialno-ekonomichni problemy suchasnoho periodu Ukrainy [Socio-economic problems of the modern period of Ukraine], 6(116), 87-90. (in Ukrainian)

Ziunkin, A.H. (2003). Finansove pravo: opornyi konspekt lektsii [Financial law: reference note of lectures]. Kyiv: Interregional Academy of Personnel Management, 159 p. (in Ukrainian) 